\title{
Optimisation of botulinum toxin type a treatment for the management of Raynaud's phenomenon using a dorsal approach: a prospective case series
}

\author{
Kiran Dhaliwal ${ }^{1,2,3,4,6}$ - Michelle F. Griffin ${ }^{1,2,3,4,6}$ (D) Sebastian Salinas ${ }^{1,2,3,4,6} \cdot$ Kevin Howell $^{1,4,5}$. \\ Christopher P. Denton ${ }^{1,4,5}$. Peter E.M. Butler ${ }^{1,2,3,4,6}$
}

Received: 15 April 2019 / Revised: 9 August 2019 /Accepted: 22 August 2019 /Published online: 3 September 2019

(C) The Author(s) 2019

\begin{abstract}
Introduction Raynaud's phenomenon (RP) is a common condition and causes pain, paraesthesia, ulceration and gangrene. Botulinum toxin A (Btx-A) is effective when injected via a digital palmar approach, in the treatment of severe RP. However, hand weakness resulting from lumbrical malfunction is a recognized complication. This study aimed to determine the effect of Btx-A injected via a dorsal approach.

Method Forty patients received 100 units of Btx-A, injected across both hands via a dorsal approach. Each patient had a baseline, 6- and 12-week hand assessment and thermographic image (FLIR E60bx) performed for the study.

Results Eighty-eight percent of patients reported an improvement in symptoms including reduction in pain, improved colour change with reduced swelling and edema at 6 weeks. Of these patients, $80 \%$ reported an improvement in cold intolerance with a reduction in the frequency and severity of Raynaud's attacks. There was a significant improvement in both the DASH score $(p=$ $0.001)$, Kapandji score $(p=0.001)$ and hand strength $(p<0.05)$. No patients reported weakness. Improvements in hand function and symptoms of RP were still evident at 12 weeks.

Conclusions Btx-A injected via a dorsal approach improves symptoms and reduces the number of RP. We have shown an effective non-surgical approach technique to treat RP.

Key Points

- Raynaud's phenomenon is a common vasospastic disorder of the digital vessels, which can cause severe pain, restrictions to hand function and ulceration.

- Dorsal botulinum toxin type A injections can improve the symptoms of secondary Raynaud's phenomenon and hand function for approximately

3 months.
\end{abstract}

Keywords Botox $\cdot$ Botulinum toxin $\cdot$ Raynauds phenomenon $\cdot$ Systemic sclerosis $\cdot$ Vasospasm

Kiran Dhaliwal and Michelle Griffin are joint first authors

Michelle F. Griffin

12michellegriffin@gmail.com

1 Charles Wolfson Center for Reconstructive Surgery, Royal Free Hospital, London, UK

2 UCL Centre for Nanotechnology and Regenerative Medicine, London, UK

3 Division of Surgery \& Interventional Science, University College London, London, UK

4 Royal Free Hospital, London, UK

5 Center for Rheumatology, UCL Division of Medicine and Royal Free London NHS Foundation Trust Hospital, London, UK

6 Plastic \& Reconstructive Surgery, Royal Free Hospital, London, UK

\section{Introduction}

Raynaud's phenomenon (RP) is a vasospastic disorder of the digital vessels triggered by exposure to cold or stress. It is most commonly observed in the hands, but also affects the toes, nose and ears [1]. Patients experience pain and paraesthesia, with persistent ischemia leading to ulceration, gangrene and possible amputation [2]. It is common, affecting up to $19 \%$ of the general population in the UK and is 9 times more likely in women than men [2]. Depending on the severity, it can have a significant impact on a patient's daily activities and quality of life [3, 4]. RP is either classified as primary or secondary. Primary RP is idiopathic [5]. Secondary RP, or Raynaud's phenomenon is associated with systemic sclerosis, Sjogren's syndrome, rheumatoid arthritis (RA) and systemic 
lupus erythematosus (SLE), vasoconstrictive and betablockers medications [5]. Systemic sclerosis is the most common cause, with secondary RP occurring in $90 \%$ of patients. Secondary RP presents with more severe disease and is more likely to have associated complications such as ulcer and gangrene $[6,7]$.

There are several treatment options for RP including medical and surgical approaches. Patients with secondary RP are often a greater clinical challenge. Distal vasospasm can be aggravated by other disease manifestations and also impact on the choice of therapy and responsiveness to vasodilator approaches [6]. Conservative, non-pharmacological measures are usually the first steps in treatment. Avoiding cold temperatures is the best method of preventing attacks [2]. Drug therapy is indicated when these measures fail to control symptoms. Calcium channel blockers, such as nifedipine, are generally considered the first-line drug treatment. They induce vasodilation of the digital vessels and have been reported to reduce the frequency and severity of attacks [8]. Another promising treatment for RP is phosphodiesterase type 5 (PDE-5) inhibitors, which cause vasodilatation through the controlling levels of intracellular cyclic guanosine monophosphate (cGMP) and cyclic adenosine monophosphate (cAMP). However, the evidence regarding which treatment is most effective is limited [9]. The treatment options for severe and refractory Raynaud's are limited. Surgical interventions, such as digital sympathectomy, have the potential for severe complications and have variable success rates $[10,11]$. Botulinum toxin $\mathrm{A}(\mathrm{Btx}-\mathrm{A})$ is a neurotoxin produced by Clostridium botulinum [2]. Btx-A offers an additional, non-operative, treatment option for these patients. It is also unique in that it provides a localised treatment [2].

Btx-A has been shown to be effective in the treatment of RP $[2,12-17]$. Most of the studies carried out to date use different injection sites including digital injections along the neurovascular bundle, in the distal palm near the superficial palmar arch and web space, and in the proximal hand at the distal volar wrist crease adjacent to the radial and ulnar arteries; however, they all use a palmar approach [12-17]. Reported complications of palmar injection include pain at the injection site, ecchymosis and intrinsic muscle weakness. The most commonly reported complication is hand weakness, with rates as high as $27 \%$ [15]. Although the paralysis is transient, it has been reported to last up to 6 months and can have a significant impact on the activities of daily living [2]. A palmar injection approach leaves the lumbricals vulnerable to the effects of the Btx-A. We hypothesised that injecting Btx-A via a dorsal approach and more distally would still be effective improving symptoms, but reduce the rates of hand weakness. This study aimed to determine the effect of Btx-A injected via a dorsal approach in patients with RP on hand function, improvement in symptoms and complication rate.

\section{Methods}

Forty patients diagnosed with secondary RP were included. For those patients with systemic sclerosis, they met the criteria for systemic sclerosis of the American College of Rheumatology grading system. Patients were excluded if they had any active infections, acute digital ischemia or any known allergies or hypersensitivity to botulinum toxin preparations, pregnant or lactating.

Data was collected prospectively at the Royal Free Hospital on 40 female patients, with an average age of 48 (25-76 years) between March 2015 and February 2016. Patient consent was obtained. We have ethical approval IRAS study number 226094 to monitor patients as per this study protocol with RP following Botox injections. All patients continued their normal medications for RP throughout the study including calcium channel blockers, iloprost, fluoxetine, PDE-5 inhibitors and losartan. All patients had RP secondary to systemic sclerosis, 20 had diffuse scleroderma and 20 had limited scleroderma with an average duration of disease of 15 years (range 5-20 years). The most common co-morbidities were hypertension, arthritis and reflux disease. None of the patients were smokers.

Each patient had a baseline hand assessment and thermographic image (FLIR E60bx) (Fig. 1a). This was carried out after a period of $20 \mathrm{~min}$ acclimatization in the temperaturecontrolled room at $23.7 \pm 2{ }^{\circ} \mathrm{C}$. Hand assessment included pinch and power grip strength measurements (Jammar plus digital pinch gauge and dynameter), range of movement of each joint in the hands using a goniometer, Kapandji thumb opposition test and a pain score using the $0-10$ visual analogue scale (VAS). Patients were asked to report any symptoms of pain, colour change, cold intolerance and complete a Disabilities of the Arm, Shoulder and Hand (DASH) score.

They were treated with a total of 100 units of Btx-A across both hands (Botox; Allergan, Marlow, UK) reconstituted with $2 \mathrm{ml}$ of normal saline by a single surgeon (MG). This was injected in equal doses via a dorsal approach, around the digital neurovascular bundles of all five digits (Fig. 1b). Both left and right hands were injected. All injections were performed by the senior author PEM Butler. To ensure the digital arteries are targeted, two injections per web space are needed and the injection was deep feeling the proximal phalanx bone during injection. Confirmation that the digital arteries were targeted with the Btx-A injections, thermography imaging was used 15 min post injection.

Post injection, patients were discharged with a Raynaud's attack diary and asked to document any further signs, symptoms and attacks they experienced for the next 6 weeks. Prior to injections, the patients gave an average number of Raynaud's attack from retrospective analysis. A telephone questionnaire was also carried out on a weekly basis, for 6 weeks. This was done to determine the presence of any complications including intrinsic hand muscle weakness and 
a

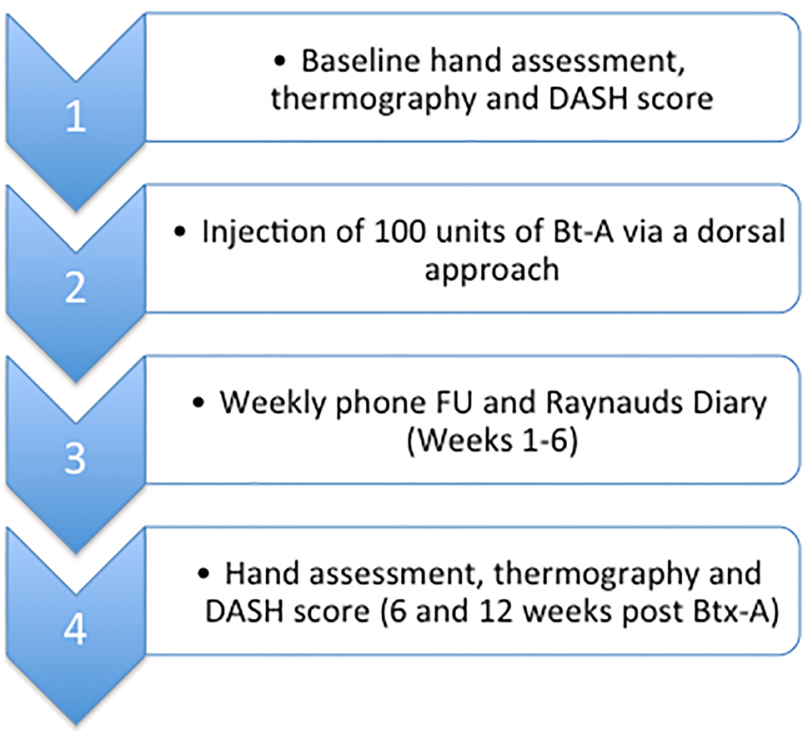

b

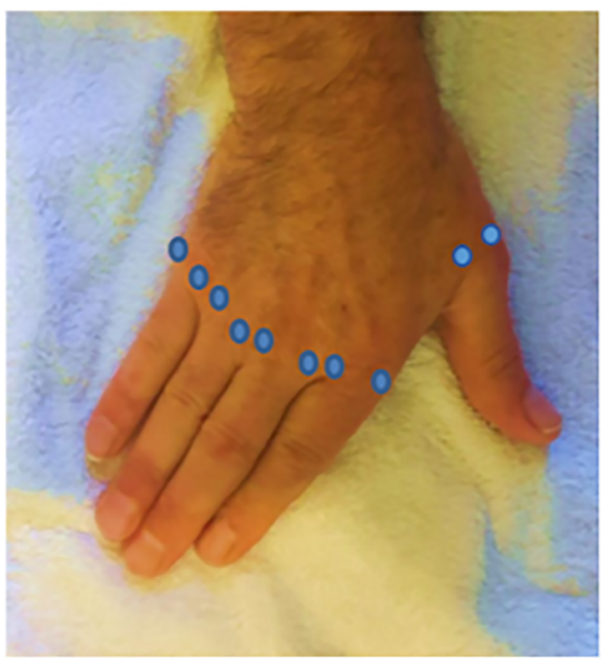

Fig. 1 Diagrams to illustrate methodology used in this paper. a Schematic to demonstrate the patient pathway from Baseline assessment pre injection to 6 and 12 weeks post injection follow up. b Diagram to

dysesthesia (abnormal sensation), headache, nausea and vomiting. After 6 weeks and 12 weeks, patients returned to have a follow-up hand assessment and thermographic imaging of the hands. Intrinisic muscle weakness was assessed by using the MRC muscle grading score. All hand assessments and thermography imaging were carried out in a temperaturecontrolled room at $23.7 \pm 2{ }^{\circ} \mathrm{C}$.

The numeric data was analysed using a paired $t$ test on SPSS. Thermographic images were analysed using FLITR Tools software (FLIR, UK). The tips of each digit (excluding thumb) were analysed using a $15 \mathrm{X} 9$ pixel region of interest measurement to determine the temperature of the digit.

\section{Results}

All patients within this cohort were female and had RP secondary to scleroderma. All of the patients had symptoms of RP despite drug therapy. One of the patients had Iloprost infusions every 4 months, three of the patients took losartan and one patient had both Iloprost infusions (6 monthly) and took losartan.

All the results compare the pre Btx-A to post Btx-A injection results recorded 6 and 12 weeks post injection.

At 6 weeks, there was a significant improvement in the DASH score, with a mean reduction in disability of 25.81 points post injection ( $p=0.001)$ (Table 1). Reduction in pain score, measured on the visual analogue scale, was also significant with a mean reduction of 5 points $(p=0.001)$ post injection (Table 1). At 12 weeks, there was a reduction in DASH scores, visual analogue scales but to lesser degrees than at 6 weeks (Table 1) $(p<0.05)$. illustrate the site of injection was around the digital neurovascular bundles of all five digits via a dorsal approach

At 6 weeks, the mean hand strength, measured using pinch and power grip, significantly increased in both the dominant and non-dominant hand post injection $(p<0.05)$ (Fig. 2). The Kapandji score decreased in both hands, increasing by 1 point in the dominant hand $(p=0.001)$ and 0.5 points in the non-dominant hand $(p<0.05)$ (Table 2). There was an overall increase in the range of movement in all joints in both the dominant and non-dominant hands post Btx-A injection (Table 2). At 12 weeks, the mean hand strength, Kapandjii score and range of movements were also significantly improved $(p<0.05)$ but to lesser degrees.

Thermographic imaging demonstrated a mean increase in the temperature of the index to the little fingers post Btx-A injection, compared to before injection (Fig. 3). There was a significant mean increase in temperature in all fingers $p$ value $(p<0.05)$ (Table 3). However, by 12 weeks, there was no change in thermographic readings.

Six weeks post Btx-A injection, $88 \%$ of patients reported an improvement in symptoms including reduction in pain, improved colour change and reduced swelling. Of these patients, $80 \%$ reported an improvement in cold intolerance with a reduction in the frequency and severity of Raynaud's attacks on average from 5 to 2.5 per week $(p<0.05)$ over the first 6 weeks. By 12 weeks, $70 \%$ of patients reported an improvement in symptoms including reduction in pain, improved colour change and reduced swelling.

Eighty-one percent of patients would have further Btx-A injections and would recommend it to other patients.

No patients had ulcers prior to the injections or developed ulcers during the study period. There was no difference in 
Table 1 Mean change in DASH and visual analogue (VAS) scores pre Botox-A (Btx-A) injection compared to post Btx-A injection. DASH and VAS score improve after BTx-A injections

\begin{tabular}{|c|c|c|c|c|}
\hline & Pre Btx-A mean score & Post Btx-A mean score 6 weeks & Post Btx-A mean score 6 weeks & $p$ value \\
\hline DASH score & $\begin{array}{l}50.62 \\
(28.46-82.67)\end{array}$ & $\begin{array}{l}25.80 \\
(10.20-72.83)\end{array}$ & $\begin{array}{l}35.80 \\
(15.20-75.83)\end{array}$ & 0.001 \\
\hline VAS score & $\begin{array}{l}5 \\
(0-9)\end{array}$ & $\begin{array}{l}1.75 \\
(0-3)\end{array}$ & $\begin{array}{l}3 \\
(1-5)\end{array}$ & 0.05 \\
\hline
\end{tabular}

hand function outcome depending on whether the patients had diffuse or systemic sclerosis.

No patients reported hand weakness as a complication. One patient reported pain at the site of injection lasting 4 days and one patient reported itching for the first 2 days. Both patients reported that these symptoms fully resolved.

\section{Discussion}

Patients with secondary RP often present with more advanced, severe disease and associated complications such as ulceration and gangrene [6, 7]. Medical therapy frequently fails to control the symptoms of severe RP and the alternative treatment
Fig. 2 Assessment of hand function before and after Botox-A (Btx-A) injections. a Pinch grip (lbs) and b power grip significantly increased after Btx-A injection in the dominant hand and non-dominant hands $(* p<0.05)$ at 6 weeks and 12 weeks

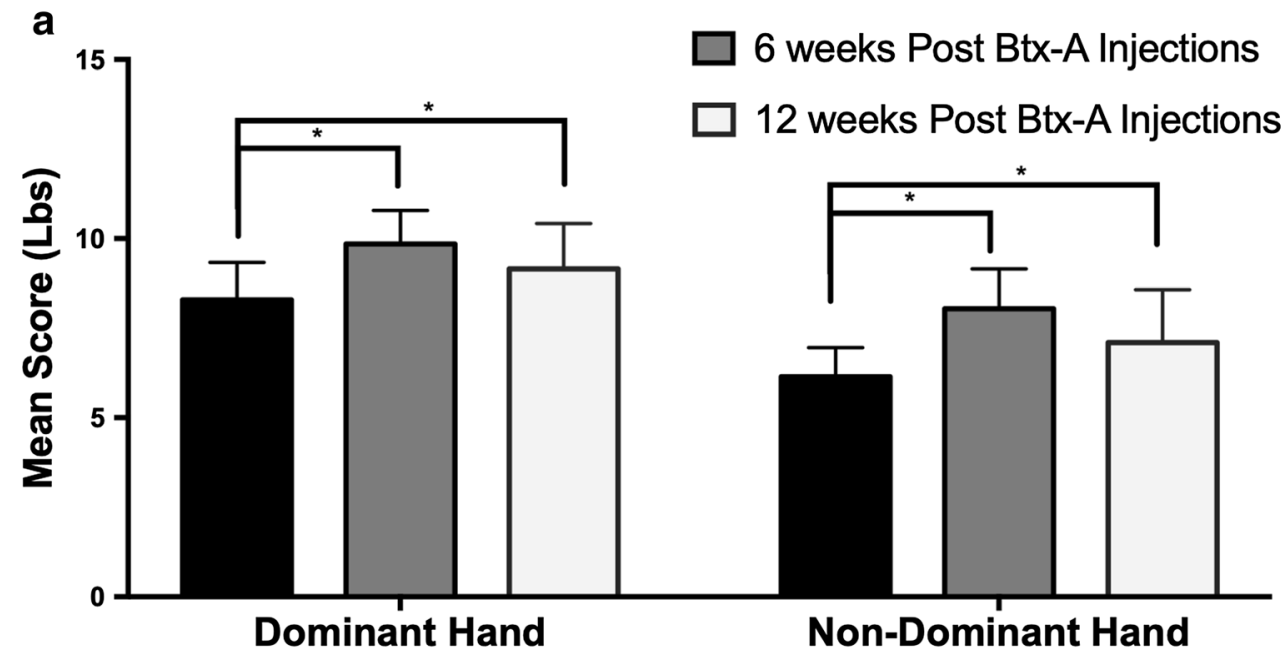

b

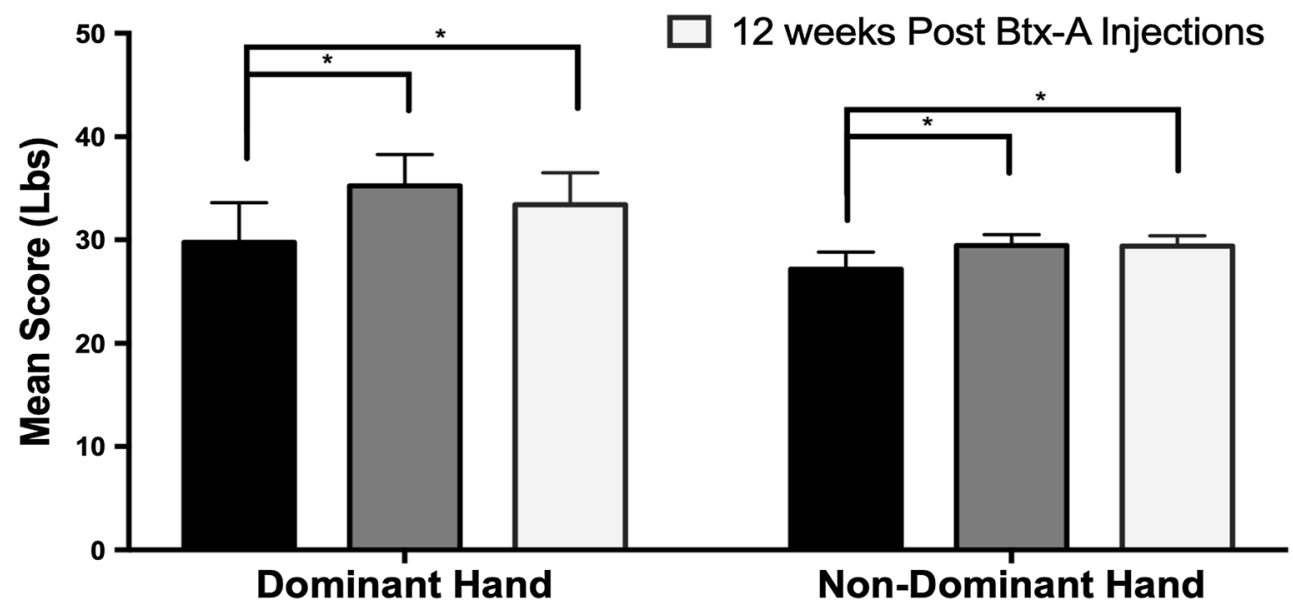


Table 2 Mean change in Kapandji score and range of movement at the joints pre Btx-A injection compared to post Btx-A injection in the dominant hand and non-dominant hands. Kapandji scores and range of movement increased after BTx-A injections

\begin{tabular}{|c|c|c|c|c|c|c|c|c|}
\hline & \multicolumn{4}{|l|}{ Dominant hand } & \multicolumn{4}{|c|}{ Non-dominant hand } \\
\hline & $\begin{array}{l}\text { Pre Btx-A injection } \\
\text { mean (range) }\end{array}$ & $\begin{array}{l}6 \text { weeks } \\
\text { Post Btx-A } \\
\text { injection mean }\end{array}$ & $\begin{array}{l}12 \text { weeks } \\
\text { Post Btx-A } \\
\text { injection mean }\end{array}$ & $p$ value & $\begin{array}{l}\text { Pre Btx-A } \\
\text { injection mean }\end{array}$ & $\begin{array}{l}6 \text { weeks } \\
\text { Post Btx-A } \\
\text { injection mean }\end{array}$ & $\begin{array}{l}12 \text { weeks } \\
\text { Post Btx-A } \\
\text { injection mean }\end{array}$ & $p$ value \\
\hline Kapandji score & $\begin{array}{l}8.8 \\
(6-10)\end{array}$ & $\begin{array}{l}9.8 \\
(8-10)\end{array}$ & $\begin{array}{l}8 \\
(8-10)\end{array}$ & 0.001 & $\begin{array}{l}9 \\
(6-10)\end{array}$ & $\begin{array}{l}9.8 \\
(9-10)\end{array}$ & $\begin{array}{l}7.5 \\
(7-10)\end{array}$ & 0.05 \\
\hline Thumb MCP & $\begin{array}{l}47 \\
(20-90)\end{array}$ & $\begin{array}{l}52 \\
(25-95)\end{array}$ & $\begin{array}{l}50 \\
(25-90)\end{array}$ & 0.001 & $\begin{array}{l}51.40 \\
(20-115)\end{array}$ & $\begin{array}{l}57.55 \\
(25-120)\end{array}$ & $\begin{array}{l}55 \\
(25-100)\end{array}$ & 0.05 \\
\hline Thumb IP & $\begin{array}{l}54 \\
(35-100)\end{array}$ & $\begin{array}{l}65 \\
(40-110)\end{array}$ & $\begin{array}{l}60 \\
(40-110)\end{array}$ & 0.029 & $\begin{array}{l}61 \\
(25-105)\end{array}$ & $\begin{array}{l}72 \\
(45-110)\end{array}$ & $\begin{array}{l}68 \\
(50-100)\end{array}$ & 0.05 \\
\hline Index MCP & $\begin{array}{l}74 \\
(40-115)\end{array}$ & $\begin{array}{l}80 \\
(45-115)\end{array}$ & $\begin{array}{l}78 \\
(45-115)\end{array}$ & 0.025 & $\begin{array}{l}79 \\
(40-100)\end{array}$ & $\begin{array}{l}83 \\
(50-110)\end{array}$ & $\begin{array}{l}80 \\
(60-100)\end{array}$ & 0.5 \\
\hline Index PIP & $\begin{array}{l}83 \\
(60-110)\end{array}$ & $\begin{array}{l}86 \\
(60-110)\end{array}$ & $\begin{array}{l}85 \\
(60-110)\end{array}$ & 0.171 & $\begin{array}{l}83 \\
(60-95)\end{array}$ & $\begin{array}{l}84 \\
(75-95)\end{array}$ & $\begin{array}{l}84 \\
(80-100)\end{array}$ & 0.82 \\
\hline Index DIP & $\begin{array}{l}56 \\
(35-85)\end{array}$ & $\begin{array}{l}70 \\
(40-110)\end{array}$ & $\begin{array}{l}65 \\
(40-100)\end{array}$ & 0.010 & $\begin{array}{l}57 \\
(45-60)\end{array}$ & $\begin{array}{l}67 \\
(45-95)\end{array}$ & $\begin{array}{l}60 \\
(45-90)\end{array}$ & 0.05 \\
\hline Middle MCP & $\begin{array}{l}80 \\
(60-105)\end{array}$ & $\begin{array}{l}85 \\
(60-115)\end{array}$ & $\begin{array}{l}83 \\
(60-110)\end{array}$ & 0.006 & $\begin{array}{l}71 \\
(55-95)\end{array}$ & $\begin{array}{l}85 \\
(55-115)\end{array}$ & $\begin{array}{l}83 \\
(55-100)\end{array}$ & 0.05 \\
\hline Middle PIP & $\begin{array}{l}75 \\
(35-105)\end{array}$ & $\begin{array}{l}85 \\
(65-110)\end{array}$ & $\begin{array}{l}76 \\
(65-110)\end{array}$ & 0.099 & $\begin{array}{l}74 \\
(45-110)\end{array}$ & $\begin{array}{l}86 \\
(60-115)\end{array}$ & $\begin{array}{l}80 \\
(60-100)\end{array}$ & 0.05 \\
\hline Middle DIP & $\begin{array}{l}60 \\
(35-90)\end{array}$ & $\begin{array}{l}67 \\
(35-100)\end{array}$ & $\begin{array}{l}66 \\
(35-100)\end{array}$ & 0.009 & $\begin{array}{l}63 \\
(40-90)\end{array}$ & $\begin{array}{l}74 \\
(55-60)\end{array}$ & $\begin{array}{l}70 \\
(60-90)\end{array}$ & 0.05 \\
\hline 4th MCP & $\begin{array}{l}74 \\
(55-95)\end{array}$ & $\begin{array}{l}79 \\
(45-100)\end{array}$ & $\begin{array}{l}78 \\
(45-100)\end{array}$ & 0.005 & $\begin{array}{l}70 \\
(45-110)\end{array}$ & $\begin{array}{l}81 \\
(45-110)\end{array}$ & $\begin{array}{l}77 \\
(50-100)\end{array}$ & 0.05 \\
\hline 4th PIP & $\begin{array}{l}75 \\
(65-110)\end{array}$ & $\begin{array}{l}87 \\
(65-110)\end{array}$ & $\begin{array}{l}85 \\
(65-110\end{array}$ & 0.929 & $\begin{array}{l}88 \\
(60-110)\end{array}$ & $\begin{array}{l}94 \\
(65-110)\end{array}$ & $\begin{array}{l}90 \\
(70-100)\end{array}$ & 0.05 \\
\hline 4th DIP & $\begin{array}{l}62 \\
(45-85)\end{array}$ & $\begin{array}{l}70 \\
(45-110)\end{array}$ & $\begin{array}{l}68 \\
(50-100)\end{array}$ & 0.016 & $\begin{array}{l}58.5 \\
(45-100)\end{array}$ & $\begin{array}{l}72.25 \\
(50-110)\end{array}$ & $\begin{array}{l}68 \\
(60-120)\end{array}$ & 0.05 \\
\hline 5th $\mathrm{MCP}$ & $\begin{array}{l}72 \\
(40-100)\end{array}$ & $\begin{array}{l}81 \\
(40-115)\end{array}$ & $\begin{array}{l}78 \\
(50-100)\end{array}$ & 0.003 & $\begin{array}{l}65.25 \\
(45-100)\end{array}$ & $\begin{array}{l}78.5 \\
(45-110)\end{array}$ & $\begin{array}{l}68 \\
(50-100)\end{array}$ & 0.05 \\
\hline 5th PIP & $\begin{array}{l}71 \\
(50-110)\end{array}$ & $\begin{array}{l}85 \\
(55-110)\end{array}$ & $\begin{array}{l}75 \\
(65-100)\end{array}$ & 0.263 & $\begin{array}{l}77.80 \\
(30-110)\end{array}$ & $\begin{array}{l}84.5 \\
(55-115)\end{array}$ & $\begin{array}{l}80 \\
(60-100)\end{array}$ & 0.05 \\
\hline 5th DIP & $\begin{array}{l}60 \\
(45-90)\end{array}$ & $\begin{array}{l}80 \\
(40-110)\end{array}$ & $\begin{array}{l}70 \\
(50-100)\end{array}$ & 0.032 & $\begin{array}{l}59.5 \\
(30-90)\end{array}$ & $\begin{array}{l}71.55 \\
(45-100)\end{array}$ & $\begin{array}{l}64 \\
(50-90)\end{array}$ & 0.05 \\
\hline
\end{tabular}

options are limited. Patients experience severe pain and disability, which significantly impacts on quality of life [3, 4]. The results of this and our previous study support the use of Btx-A as a treatment option for such patients. RP can be severe to cause problems with range of movement and grip due to pain, swelling, ulcers and gangrene. This studies shows that Btx-A injected via a dorsal approach significantly reduces pain and disability, increases hand strength, Kapandji score and blood flow to the digits. The majority of patients also reported an improvement in symptoms, number and severity of attacks. The response to the Btx-A for the treatment of the RP was highly evidence at 6 weeks and 12 weeks, but its effect has decreased by 12 weeks as shown by the hand function assessment tool.

Our group and others have looked at the use of Btx-A as a treatment for RP [2, 12-23]. The first case series in 2004 by Schya et al. [12] included both patients with primary and secondary RP with improvements in VAS pain scores and laser Doppler. Van Beek et al. found similar improvements in 11 patients with RP with 100 units of Bt-A including patients with acute digital ischemia.15 The largest cohort of 33 patients by Neumeister et al. showed improved perfusion with 100 units of Bt-A with all but five patients reporting improvements in pain and vascularity [16]. Overall, these thirteen studies all support the use of Btx-A may be an effective treatment for RP but also importantly highlight a need for larger randomised controlled trials [2, 12-23]. All reported studies that use a palmar injection approach sites include digital injections along the neurovascular bundle, in the distal palm within the superficial palmar arch and web space, and in the proximal hand at the distal volar wrist crease adjacent to the radial and ulnar arteries. However, a palmar approach has associated complications including intrinsic hand muscle weakness and dysesthesia (abnormal sensation) [17]. Hand weakness in these studies was common and affected between 9 and $27 \%$ of patients $[2,14-18]$. None of the 40 patients injected via a dorsal approach in this study reported hand weakness as a complication. We hypothesise that injecting via a dorsal distal approach prevents lumbrical injections, and consequently lumbrical weakness. Our research group 
Fig. 3 Examples of three patients thermographic imaging before and after Botox-A (Btx-A) injections. The images demonstrate an increase in temperature $(0 \mathrm{C})$ from pre Btx-A (a, c, e) to post Btx-A injection $(\mathbf{b}, \mathbf{d}, \mathbf{f})$ in the dominant hand and non-dominant hands at 6 weeks

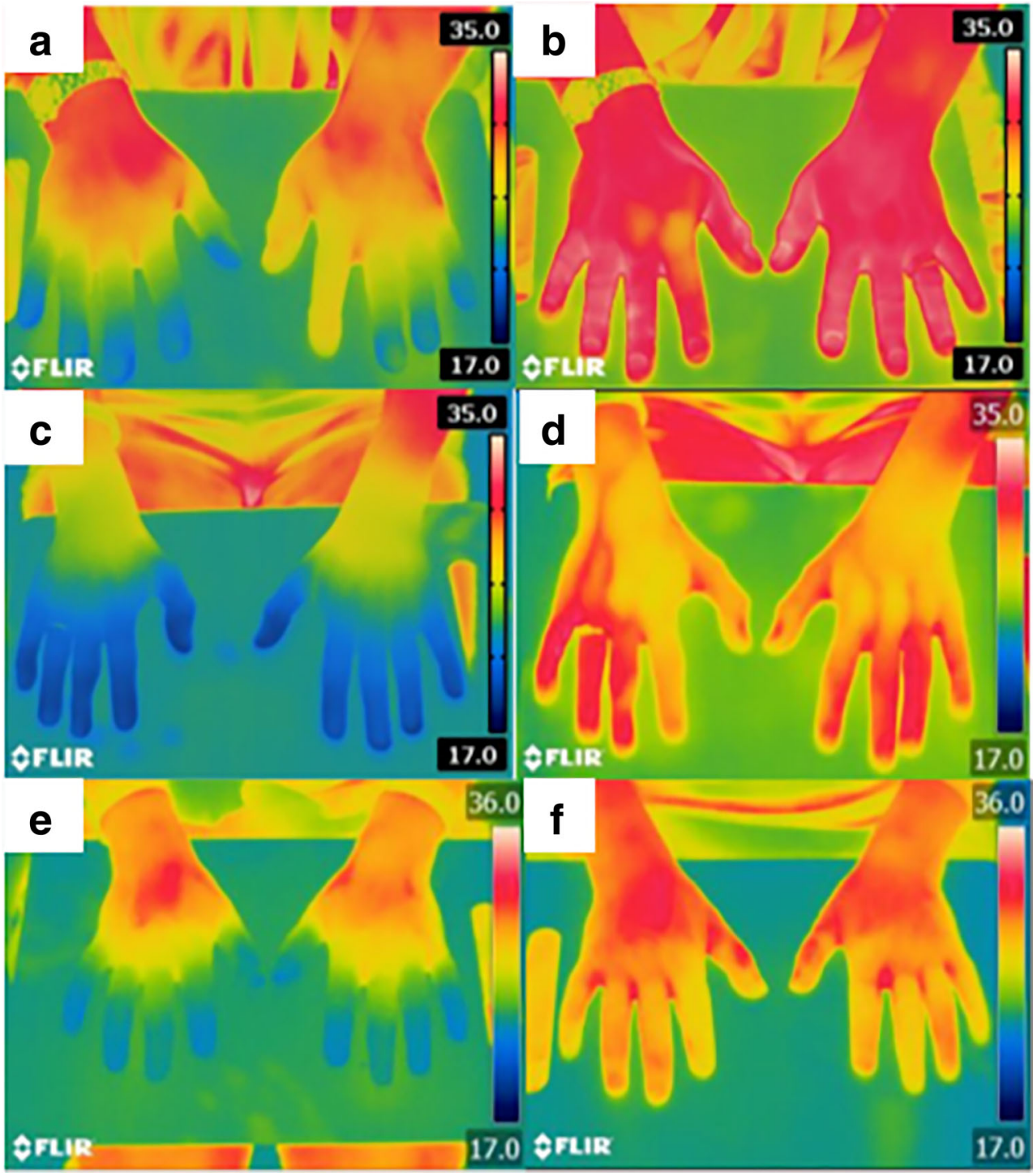

carried out a similar study in 2014, looking at the effects of Btx-A injected via a palmar approach on RP secondary to systemic sclerosis. This study found that two patients reported the complication of hand weakness when Btx-A was injected via a palmar approach. Although it resolved in both case, it was reported to last as long as 12 weeks [2]. Injecting via a

Table 3 Mean change in temperature $\left({ }^{\circ} \mathrm{C}\right)$ from thermographic imaging pre Btx-A injection compared to post Btx-A injection in the dominant hand and non-dominant hands. There was an increase in the temperature of the hand as shown by thermographic imaging after Btx-A injections

\begin{tabular}{|c|c|c|c|c|c|c|}
\hline & \multicolumn{3}{|l|}{ Dominant hand } & \multicolumn{3}{|l|}{ Non-dominant hand } \\
\hline & $\begin{array}{l}\text { Mean temperature } \\
\left({ }^{\circ} \mathrm{C}\right) \text { pre Btx-A }\end{array}$ & $\begin{array}{l}\text { Mean temperature } \\
\left({ }^{\circ} \mathrm{C}\right) \text { post } \mathrm{Btx}-\mathrm{A}\end{array}$ & $p$ value & $\begin{array}{l}\text { Mean temperature } \\
\left({ }^{\circ} \mathrm{C}\right) \text { pre Btx-A }\end{array}$ & $\begin{array}{l}\text { Mean temperature } \\
\left({ }^{\circ} \mathrm{C}\right) \text { post } \mathrm{Btx}-\mathrm{A}\end{array}$ & $p$ value \\
\hline Index finger & $\begin{array}{l}25.5 \\
(20.1-29.3)\end{array}$ & $\begin{array}{l}30.45 \\
(28-34.8)\end{array}$ & 0.0001 & $\begin{array}{l}25.45 \\
(20-31.4)\end{array}$ & $\begin{array}{l}31.25 \\
(26.5-34.8)\end{array}$ & 0.0001 \\
\hline Middle finger & $\begin{array}{l}25.39 \\
(20.2-29.8)\end{array}$ & $\begin{array}{l}30.3 \\
(25.9-34.9)\end{array}$ & 0.0001 & $\begin{array}{l}25.30 \\
(19.6-28.2)\end{array}$ & $\begin{array}{l}31 \\
(27.1-34.7)\end{array}$ & 0.0001 \\
\hline Ring finger & $\begin{array}{l}24.5 \\
(20.2-29.7)\end{array}$ & $\begin{array}{l}30.8 \\
(25.8-34.7)\end{array}$ & 0.0001 & $\begin{array}{l}24.5 \\
(20.5-29.2)\end{array}$ & $\begin{array}{l}29.25 \\
(24.9-34.5)\end{array}$ & 0.0001 \\
\hline Little finger & $\begin{array}{l}25.10 \\
(20.1-29.5)\end{array}$ & $\begin{array}{l}30.90 \\
(25.4-34.9)\end{array}$ & 0.0001 & $\begin{array}{l}25.15 \\
(20.5-32.2)\end{array}$ & $\begin{array}{l}30.30 \\
(27.8-34.3)\end{array}$ & 0.001 \\
\hline
\end{tabular}


palmar approach leaves the lumbricals vulnerable to the effects of the Btx-A. The lumbricals are protected from the effects of Btx-A when a dorsal approach is used, reducing the risk of hand weakness occurring due to the muscle anatomical location. One patient reported ongoing pain at the injection site, but symptoms resolved fully within 4 days. No other patients reported lasting pain after injection. In comparison, pain at injection site after palmar injection has been reported as high as $75-100 \%$ in the literature [16].

One other study has investigated the effect of Btx-A injected via a dorsal approach [24]. Bello et al. performed a randomised double-blind placebo controlled clinical trial in patients with scleroderma associate RP using Btx-A in one randomly selected hand and sterile saline in the opposite hand [24]. This study followed 40 patients for 1 and 4 months post injection using laser Doppler imaging, patient-reported outcomes and physical exam. They found improved QuickDASH, Mc Cabe scores, VAS scores and significant improvement in Raynauds Condition Score. However, at 4 months, there was no significant difference in blood flow. The differences found between their study and our study can be accounted for by small differences in technique used to administer the Btx-A, protocol and follow-up times. Bello et al. reviewed patients after 4 months, at which the time the effect may have been lost as described by the authors [24]. The authors also describe injecting Btx-A via the web spaces using single injection of the $2 \mathrm{nd}, 3 \mathrm{rd}$ and 4 th webspace but do not comment on depth or exact position. We have found that to ensure you target the digital arteries, two injections per web space is needed and the injection must be deep feeling the proximal phalanx bone as you inject. We also confirmed after $15 \mathrm{~min}$ from the injection that the digital arteries have been targeted by demonstrated vasodilation over the metacarpal joints using thermography imaging. Further evidence highlights that a slightly different technique was used between the two studies, as Bello et al. reports a 5\% weakness but this study had no participants with this complication.

Several mechanisms have been proposed for the potential effect of Btx-A on RP. Our study found that temperature to the digits is significantly improved after Btx-A injection [12, 13, 16]. Animal studies have shown it increases vascular blood flow by inhibiting sympathetic vasoconstriction [25]. The thermography imaging and hand assessment data in this study supports this theory.

One limitation of this study is the lack of randomisation; however, this study demonstrates a promising technique to improve in pain, disability, Kapandji score and digit temperature. However, further randomised and controlled studies are needed to quantify its efficacy relative to other medical and surgical treatments to ascertain Btx-A true efficacy. A further interesting observation is that many of the patients had concurrent medical management for their RP, including losartan and Iloprost infusion. The participants had been on the medication for several years. These patients reported a noticeable improvement in their symptoms following Btx-A injection despite being on concurrent medical management for their RP. Future work will investigate whether the effect is similar in patients with different grades of systemic sclerosis and taking into consideration treatments regimes. Lastly, in this study, we observed that the results lasted approximately 12 weeks. Future studies should investigate whether a higher dose of Btx-A may provide symptom relief for a longer period. A previous review highlighted that previous studies provide a range of botulinum toxin injections but the appropriate dose and frequency is less clear [5].

Severe RP is often refractory to treatment and presents a significant problem for both the patient and clinician. Patients with RP experience severe pain and disability with limited options available. In conclusion, our results support the use of Btx-A, injected via a dorsal approach, to be an effective and safe treatment for secondary RP. Patients had a significant improvement in their symptoms and disability, improved hand strength, Kapandji score and digit temperature. Future work will include performing a randomized control trial using our optimised technique in patients with secondary RP.

Acknowledgements We would like to thank Rebecca Canny for her contribution to organizing the hand clinics.

\section{Compliance with ethical standards}

\section{Disclosures None.}

Open Access This article is distributed under the terms of the Creative Commons Attribution 4.0 International License (http:// creativecommons.org/licenses/by/4.0/), which permits unrestricted use, distribution, and reproduction in any medium, provided you give appropriate credit to the original author(s) and the source, provide a link to the Creative Commons license, and indicate if changes were made.

\section{References}

1. Flavahan NA (2015) Pathophysiological regulation of the cutaneous vascular system in Raynaud's phenomenon. Raynaud's Phenomenon: Springer, pp 57-79

2. Uppal L, Dhaliwal K, Butler P (2014) A prospective study of the use of botulinum toxin injections in the treatment of Raynaud's syndrome associated with systemic sclerosis. J Hand Surg Eur Vol 39:876-880

3. Silman A, Holligan S, Brennan P, Maddison P (1990) Prevalence of symptoms of Raynaud's phenomenon in general practice. BMJ 301:590-592

4. De Trafford J, Lafferty K, Potter C et al (1988) An epidemiological survey of Raynaud's phenomenon. Eur J Vasc Surg 2:167-170

5. Iorio ML, Masden DL, Higgins JP, editors (2012) Botulinum toxin A treatment of Raynaud's phenomenon: a review. Seminars in arthritis and rheumatism. Elsevier

6. Ong VH, Denton CP (2015) Secondary Raynaud's phenomenon. Raynaud's Phenomenon: Springer, pp 107-27 
7. Rosenkranz S, Diet F, Karasch T, Weihrauch J, Wassermann K, Erdmann E (2003) Sildenafil improved pulmonary hypertension and peripheral blood flow in a patient with systemic sclerosisassociated lung fibrosis and the raynaud phenomenon. Ann Intern Med 139:871-873

8. Chung L, Shapiro L, Fiorentino D, Baron M, Shanahan J, Sule S, Hsu V, Rothfield N, Steen V, Martin RW, Smith E, Mayes M, Simms R, Pope J, Kahaleh B, Csuka ME, Gruber B, Collier D, Sweiss N, Gilbert A, Dechow FJ, Gregory J, Wigley FM (2009) MQX-503, a novel formulation of nitroglycerin, improves the severity of Raynaud's phenomenon: a randomized, controlled trial. Arthritis Rheum 60:870-877

9. Levien TL (2010) Advances in the treatment of Raynaud's phenomenon. Vasc Health Risk Manag 6:167-177

10. Wigley FM, Herrick AL (2015) Management of Raynaud's Phenomenon and digital ulcers. Curr Treat Opt Rheumatol 1:68-81

11. Landry GJ (2013) Current medical and surgical management of Raynaud's syndrome. J Vasc Surg 57:1710-1716

12. Sycha T, Graninger M, Auff E, Schnider P (2004) Botulinum toxin in the treatment of Raynaud's phenomenon: a pilot study. Eur J Clin Investig 34:312-313

13. Neumeister MW, Chambers CB, Herron MS et al (2009) Botox therapy for ischemic digits. PRS 124:191-201

14. Fregene A, Ditmars D, Siddiqui A (2009) Botulinum toxin type A: a treatment option for digital ischemia in patients with Raynaud's phenomenon. J Hand Surg Am 34A:446-452

15. Van Beek AL, Lim PK, Gear AJ et al (2007) Management of vasospastic disorders with botulinum toxin A. PRS 119:217-226

16. Neumeister MW (2010) Botulinum toxin type A in the treatment of Raynaud's phenomenon. J Hand Surg Am 35A:2085-2092

17. Kossintseva I, Barankin B (2008) Improvement in both Raynaud disease and hyperhidrosis in response to botulinum toxin type A treatment. J Cutan Med Surg 12:189-193
18. Smith L, Polsky D, Franks AG (2012) Botulinum toxin-A for the treatment of Raynaud syndrome. Arch Dermatol 148:426-428

19. Zhao H, Lian Y (2015) Clinical and image improvement of Raynaud's phenomenon after botulinum toxin type A treatment. Australas J Dermatol 56:202-205

20. Jenkins SN, Neyman KM, Veledar E et al (2013) A pilot study evaluating the efficacy of botulinum toxin A in the treatment of Raynaud phenomenon. J Am Acad Dermatol 5:834-835

21. Zhang $X, \mathrm{Hu}$ Y, Nie Z, Song Y, Pan Y, Liu Y, Jin L (2015) Treatment of Raynaud's phenomenon with botulinum toxin type A. Neurol Sci 36:1225-1231

22. Si M, Yamada K, Toki S et al (2016) Beneficial effect of botulinum toxin A on Raynaud's phenomenon in Japanese patients with systemic sclerosis: a prospective, case series study. J Dermatol 43:5662

23. Serri J, Legre R, Veit V, Guardia C, Gay A, editors (2013) [Botulinum toxin type A contribution in the treatment of Raynaud's phenomenon due to systemic sclerosis]. Annales de chirurgie plastique et esthetique

24. Bello RJ, Cooney CM, Melamed E, Follmar K, Yenokyan G, Leatherman G, Shah AA, Wigley FM, Hummers LK, Lifchez SD (2017) The therapeutic efficacy of botulinum toxin in treating scleroderma-associated Raynaud's phenomenon: a randomized, double-blind, placebo-controlled clinical trial. Arthritis Rheumatol 69:1661-1669

25. Stone AV, Koman LA, Callahan MF et al (2012) The effect of botulinum neurotoxin-A on blood flow in rats: a potential mechanism for treatment of Raynaud phenomenon. J Hand Surg Am 37A: 795-802

Publisher's note Springer Nature remains neutral with regard to jurisdictional claims in published maps and institutional affiliations. 